\title{
Varietal Evaluation of Gladiolus for Flowering Attributes Under Indo-Gangetic Plains
}

\author{
Anil K. Singh, Dhananjay Kumar*, Anjana Sisodia and Minakshi Padhi \\ Department of Horticulture, Institute of Agricultural Sciences \\ Banaras Hindu University, Varanasi, U.P., India \\ *Corresponding author
}

Keywords

Gladiolus,

Cultivars,

Flowering

Article Info

Accepted:

26 June 2018

Available Online:

10 July 2018

\section{A B S T R A C T}

The present investigation was carried out to evaluate the gladiolus varieties for various flowering traits at Horticulture Research Farm, Department of Horticulture, Institute of Agricultural Sciences, Banaras Hindu University, Varanasi during 2017-18. The experiment was conducted in Randomized Block Design comprised of 31 varieties of gladiolus and replicated three times. The mean performance of gladiolus varieties was significant for all the flowering characters studied. The data concluded that cultivar Priscilla was earlier in spike emergence, days to opening $1^{\text {st }}, 3^{\text {rd }}$ and $5^{\text {th }}$ florets. Cultivar Jyotsana resulted in early colour show, whereas, cv. FlevoLeguna was found late. Cultivar Shabanam produced larger length of spike and length of rachis, whereas cv. Darshan was shortest for length of spike. Maximum number of open floret at a time was observed in the cultivar Nova Lux and minimum in cv. Punjab Morning. Highest longevity of $1^{\text {st }}$ floret was observed in cultivar Pink Friendship, whereas $3^{\text {rd }}$ and $5^{\text {th }}$ with cv. Trader Horn. Maximum diameter of $1^{\text {st }}, 3^{\text {rd }}$ and $5^{\text {th }}$ floret was recorded with cultivar Pink Friendship and minimum in cv. Flevo Leguna. Cultivar Shubhangini exhibited maximum for longevity of spike which was statistically at par with cultivars Tiger Flame and Pink Friendship.

\section{Introduction}

Gladiolus is an important commercial flower and is very popular as cut flower both in domestic and international market (Singh and Sisodia, 2017) and it is one of the most popular bulbous flower which belongs to family Iridaceae and subfamily Ixioideae. There are about 260 species and over 30,000 varieties of gladiolus (Singh, 2014). Especially for gladiolus crop in which every year a great number of new varieties are introduced, it is difficult for the user to obtain enough information to judge the value of these varieties. In that case, varietal evaluation of new cultivars and existing cultivar is necessary to determine the value of these cultivars and to distribute this information. This will also contribute in making good varieties better known, while on the other hand varieties with little prospect are sooner identified which makes it possible to stop unnecessarily loss of capital by investing in these varieties. Flowering characters of spike 
determines greatly for suitability of variety or genotype for production. To meet the necessity of the above requirement research work has been carried out with the title "Varietal evaluation of gladiolus for flowering attributes under indo-gangetic plains".

\section{Materials and Methods}

A field experiment was carried outat Horticulture Research Farm of the Department of Horticulture, Institute of Agricultural Sciences, Banaras Hindu University, Varanasi. Experiment consisted of 31 cultivars of gladiolus, viz., Pink Friendship, Jyotsana, Sunanya, Green, Yellow Star, Anjali, PusaSubham, Arti, BTS, Trader Horn, FlevoLeguna, Surya Kiran, Punjab Morning, IIHR, American Beauty, Nova Lux, Punjab Dawn, Priscilla, Aldebaran, Dhanvantari, Princess Margaret Rose, PusaSrijan, Subhangini, Jester Gold, Purple Flora, Chemistry, Darshan, Shabanam, Chandini, Pusa Kiran and Tiger Flame during winter season of 2017-18. Varanasi is situated at $25^{\circ}$ $02^{\prime}$ North latitude, $83^{\circ} 03^{\prime}$ East longitudes and at an elevation of 128.93 meters above sea level. The experiment was laid out in Randomized Block Design and replicated three times. All cultural operations were uniformly done for all the varieties. Observations were recorded on various flowering characters and data were analysed statistically.

\section{Results and Discussion}

The analysis of varietal performance revealed that treatments were significant for all flowering characters indicating varietal differences for all characters studied (Table 1). The cultivar Priscilla resulted in early spike emergence (59.00 days) which was at par with cultivars American Beauty (62.64 days) and IIHR (62.89 days) and followed by the cultivars Sunanya (63.83 days) and Pusa Kiran (63.83 days). However, it was significantly earlier than other cultivars. Cv. FlevoLeguna (88.17 days) took maximum number of days to spike emergence. The earliest for days to colour show (75.22 days) was exhibited in cv. Jyotsana which was statistically at par with variety Priscilla (79.11 days) and followed by the cultivars American Beauty (81.72), Pusa Kiran (81.50), and Punjab Dawn (82.78). The cultivar Flevo Leguna was latest to show colour (101.16 days). Difference in days to spike emergence and days to colour show were also advocated by Kumar, (2009), Shaukatet al., (2012) and Kadamet al., (2014), Chourasiaet al., (2015). The data reveals that the minimum days to full bloom of first (83.22 days), third (85.11 days) and fifth (86.33 days) floret was observed with cultivar Priscilla which was statistically significant to all other varieties, whereas the maximum number of days to open first (105.00 days), third (106.50 days) and fifth (107.50 days) floret was recorded in cultivar FlevoLeguna. The diameter of first and fifth florets was significantly higher in the cultivar Pink Friendship, whereas, BTS for third floret and found minimum in cultivar FlevoLeguna for first third and fifth floret (Fig. 1). Differences in diameter of the florets were reported by Pandey et al., (2012) and Kadam et al., (2014). The length of spike was maximum in cultivar Shabanam $(113.23 \mathrm{~cm})$ followed by the cultivars Shubhangini $(94.52 \mathrm{~cm})$, Tiger Flame $(93.04 \mathrm{~cm})$ and Pusa Kiran $(89.13 \mathrm{~cm})$, whereas it was significantly higher than other cultivars. The longest rachis length was also recorded in cultivar Shabanam $(75.23 \mathrm{~cm})$ which was superior to rest all other cultivars and followed by the cultivars Shubhangini $(62.20 \mathrm{~cm})$, Pink Friendship $(55.26 \mathrm{~cm})$ and Tiger Flame $(53.73 \mathrm{~cm})$. The variation in length of spike and length of rachis is also observed by Susila (2013), Sarkar and Chakraborty (2014), Sindhu et al., (2014), Naresh et al., (2015) Chourasia et al., (2015), Singh et al., (2017), Swaroop et al., (2017), Mushtaq et al., (2018). 
Table.1 Performance of gladiolus varieties for days to spike emergence, days to colour show, days to open first, third and fifth floret, length of spike and length of rachis

\begin{tabular}{|c|c|c|c|c|c|c|c|}
\hline Treatment & $\begin{array}{c}\text { Days to spike } \\
\text { emergence }\end{array}$ & $\begin{array}{l}\text { Days to colour } \\
\text { show }\end{array}$ & $\begin{array}{l}\text { Days to open } 1^{\text {st }} \\
\text { floret }\end{array}$ & $\begin{array}{l}\text { Days to open } 3^{\text {rd }} \\
\text { floret }\end{array}$ & $\begin{array}{l}\text { Days to open } 5^{\text {th }} \\
\text { floret }\end{array}$ & $\begin{array}{l}\text { Length of spike } \\
\text { (cm) }\end{array}$ & $\begin{array}{l}\text { Length of rachis } \\
(\mathrm{cm})\end{array}$ \\
\hline Pink Friendship & 69.00 & 85.00 & 88.83 & 91.17 & 92.83 & 80.00 & 55.27 \\
\hline Jyotsana & 64.11 & 75.22 & 86.22 & 89.00 & 89.56 & 67.21 & 32.29 \\
\hline Sunanya & 63.83 & 83.56 & 87.39 & 89.33 & 91.28 & 74.94 & 44.71 \\
\hline Green & 86.17 & 96.83 & 100.17 & 101.83 & 103.00 & 68.60 & 38.20 \\
\hline Yellow Star & 71.17 & 86.50 & 91.00 & 93.00 & 95.00 & 67.34 & 39.08 \\
\hline Anjali & 79.28 & 95.28 & 98.22 & 99.94 & 101.47 & 81.55 & 46.54 \\
\hline PusaSubham & 77.44 & 90.22 & 94.11 & 95.78 & 96.78 & 53.61 & 29.14 \\
\hline Arti & 81.94 & 96.39 & 100.33 & 102.11 & 104.00 & 63.83 & 38.74 \\
\hline BTS & 78.00 & 91.67 & 97.00 & 98.33 & 99.33 & 77.87 & 26.00 \\
\hline Trader Horn & 79.17 & 92.50 & 97.83 & 99.67 & 100.83 & 72.23 & 39.35 \\
\hline FlevoLeguna & 88.17 & 101.17 & 105.00 & 106.50 & 107.50 & 59.32 & 35.92 \\
\hline Surya Kiran & 77.83 & 90.94 & 95.00 & 96.67 & 98.28 & 62.67 & 33.74 \\
\hline Punjab Morning & 72.00 & 86.22 & 91.44 & 93.33 & 94.56 & 61.98 & 27.99 \\
\hline IIHR & 62.89 & 84.11 & 89.06 & 91.17 & 93.39 & 83.75 & 44.82 \\
\hline American Beauty & 62.64 & 81.72 & 87.28 & 88.69 & 89.78 & 79.82 & 48.53 \\
\hline Nova Lux & 76.89 & 93.56 & 96.56 & 97.78 & 99.00 & 88.91 & 43.93 \\
\hline Punjab Dawn & 67.22 & 82.78 & 86.44 & 88.67 & 90.22 & 64.63 & 33.09 \\
\hline Priscilla & 59.00 & 79.11 & 83.22 & 85.11 & 86.33 & 74.81 & 42.94 \\
\hline Aldebaran & 77.00 & 90.67 & 95.17 & 97.00 & 98.33 & 69.78 & 37.08 \\
\hline Dhanvantari & 84.56 & 99.19 & 102.72 & 104.36 & 105.36 & 88.01 & 47.71 \\
\hline Princess Margaret Rose & 71.61 & 88.33 & 91.39 & 92.50 & 94.44 & 80.74 & 45.13 \\
\hline PusaSrijan & 78.81 & 93.92 & 96.39 & 97.97 & 99.11 & 83.97 & 41.75 \\
\hline Shubhangini & 69.69 & 86.17 & 90.14 & 92.14 & 93.78 & 94.52 & 62.20 \\
\hline Jester Gold & 80.94 & 96.00 & 99.28 & 100.89 & 102.28 & 78.87 & 35.36 \\
\hline Purple Flora & 64.89 & 84.72 & 87.72 & 89.61 & 91.00 & 63.53 & 31.06 \\
\hline Chemistry & 65.28 & 84.28 & 87.89 & 89.61 & 91.33 & 84.62 & 48.99 \\
\hline Darshan & 81.78 & 95.44 & 100.33 & 101.78 & 103.45 & 52.80 & 34.84 \\
\hline Shabanam & 78.00 & 92.00 & 97.00 & 98.33 & 99.67 & 113.23 & 75.23 \\
\hline Chandni & 68.67 & 86.11 & 91.00 & 92.89 & 95.11 & 72.02 & 32.22 \\
\hline Pusa Kiran & 63.83 & 81.50 & 86.08 & 87.67 & 89.00 & 89.13 & 49.83 \\
\hline Tiger Flame & 85.08 & 98.50 & 102.17 & 104.08 & 104.92 & 93.05 & 53.73 \\
\hline C.D. $5 \%$ & 4.21 & 4.53 & 2.86 & 2.75 & 2.66 & 11.27 & 7.13 \\
\hline
\end{tabular}


Table.2 Performance of gladiolus varieties for number of open floret at a time, length of first, third and fifth floret, number of florets per spike, and longevity of spike

\begin{tabular}{|c|c|c|c|c|c|c|}
\hline Treatment & $\begin{array}{l}\text { Number of open } \\
\text { floret at a time }\end{array}$ & $\begin{array}{l}\text { Number of floret per } \\
\text { spike }\end{array}$ & $\begin{array}{l}\text { Length of } 1^{\text {st }} \text { floret } \\
(\mathrm{cm})\end{array}$ & $\begin{array}{l}\text { Length of } 3^{\text {rd }} \text { floret } \\
(\mathrm{cm})\end{array}$ & $\begin{array}{l}\text { Length of } 5^{\text {th }} \text { floret } \\
(\mathrm{cm})\end{array}$ & $\begin{array}{l}\text { Longevity of spike } \\
\text { (days) }\end{array}$ \\
\hline Pink Friendship & 8.17 & 18.67 & 11.05 & 10.35 & 10.17 & 16.67 \\
\hline Jyotsana & 5.33 & 9.78 & 10.09 & 9.94 & 9.30 & 11.89 \\
\hline Sunanya & 5.72 & 12.89 & 10.01 & 9.78 & 9.73 & 16.00 \\
\hline Green & 6.50 & 11.17 & 8.70 & 8.85 & 8.27 & 10.33 \\
\hline Yellow Star & 7.33 & 12.67 & 10.97 & 9.90 & 10.05 & 14.50 \\
\hline Anjali & 5.19 & 13.47 & 9.59 & 10.02 & 9.21 & 12.31 \\
\hline PusaSubham & 5.22 & 10.89 & 10.20 & 9.86 & 9.33 & 13.22 \\
\hline Arti & 5.33 & 10.89 & 10.66 & 10.41 & 10.15 & 11.94 \\
\hline BTS & 6.33 & 8.00 & 10.60 & 10.57 & 10.17 & 12.33 \\
\hline Trader Horn & 7.33 & 8.67 & 9.87 & 9.67 & 9.17 & 11.33 \\
\hline FlevoLeguna & 5.50 & 15.33 & 8.32 & 7.93 & 7.68 & 14.17 \\
\hline Surya Kiran & 5.67 & 10.94 & 10.70 & 10.51 & 9.95 & 12.50 \\
\hline Punjab Morning & 4.89 & 9.00 & 9.37 & 9.23 & 8.83 & 11.89 \\
\hline IIHR & 5.89 & 11.28 & 10.67 & 10.26 & 10.11 & 14.72 \\
\hline American Beauty & 7.11 & 12.64 & 11.21 & 10.95 & 10.88 & 14.72 \\
\hline Nova Lux & 8.00 & 14.00 & 10.51 & 10.23 & 10.07 & 12.44 \\
\hline Punjab Dawn & 5.89 & 13.33 & 8.97 & 9.07 & 8.84 & 13.22 \\
\hline Priscilla & 7.00 & 12.44 & 10.73 & 10.74 & 10.40 & 14.89 \\
\hline Aldebaran & 5.33 & 6.50 & 9.77 & 9.47 & 9.15 & 9.83 \\
\hline Dhanvantari & 6.31 & 12.33 & 11.18 & 11.10 & 10.65 & 12.31 \\
\hline Princess Margaret Rose & 6.83 & 13.33 & 9.07 & 9.63 & 9.20 & 13.83 \\
\hline PusaSrijan & 5.22 & 9.75 & 8.80 & 8.83 & 8.84 & 10.31 \\
\hline Shubhangini & 5.33 & 17.72 & 10.86 & 10.77 & 10.81 & 17.33 \\
\hline Jester Gold & 5.83 & 9.94 & 10.05 & 9.97 & 9.27 & 13.00 \\
\hline Purple Flora & 6.17 & 10.50 & 8.89 & 8.42 & 8.61 & 11.28 \\
\hline Chemistry & 6.06 & 13.61 & 10.46 & 10.25 & 9.95 & 14.56 \\
\hline Darshan & 5.22 & 10.78 & 9.87 & 9.63 & 9.24 & 13.61 \\
\hline Shabanam & 5.00 & 16.67 & 10.90 & 11.30 & 10.37 & 14.00 \\
\hline Chandni & 5.78 & 8.11 & 9.08 & 9.10 & 9.09 & 12.11 \\
\hline Pusa Kiran & 6.75 & 16.42 & 9.93 & 10.07 & 9.26 & 15.92 \\
\hline Tiger Flame & 7.22 & 15.78 & 11.04 & 10.62 & 10.40 & 16.78 \\
\hline C.D. $5 \%$ & 0.82 & 2.35 & 0.62 & 0.62 & 0.64 & 1.64 \\
\hline
\end{tabular}


Fig.1 Performance of gladiolus varieties for diameter of first, third and fifth floret

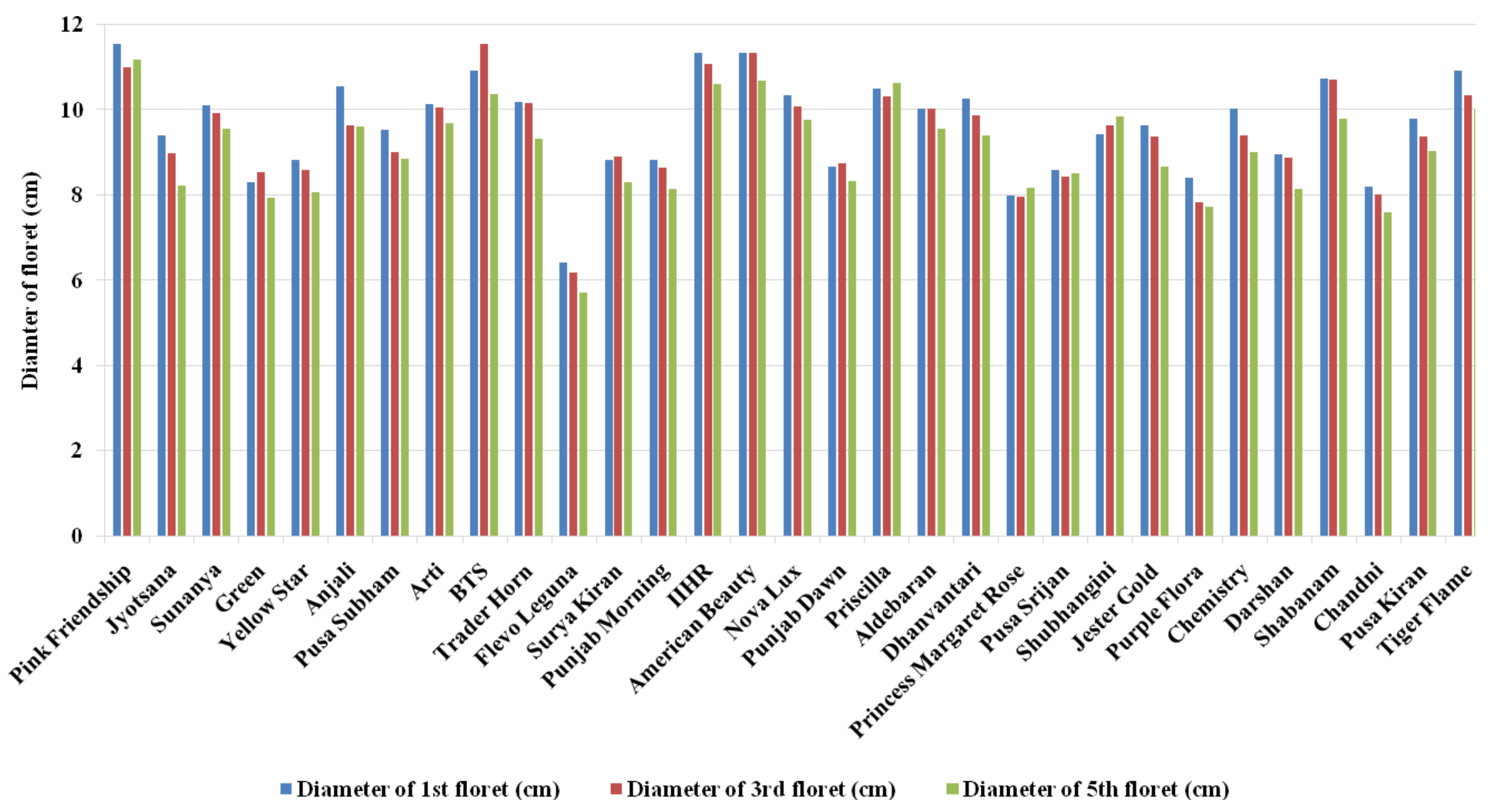


Fig.2 Performance of gladiolus varieties for longevity of first, third and fifth floret

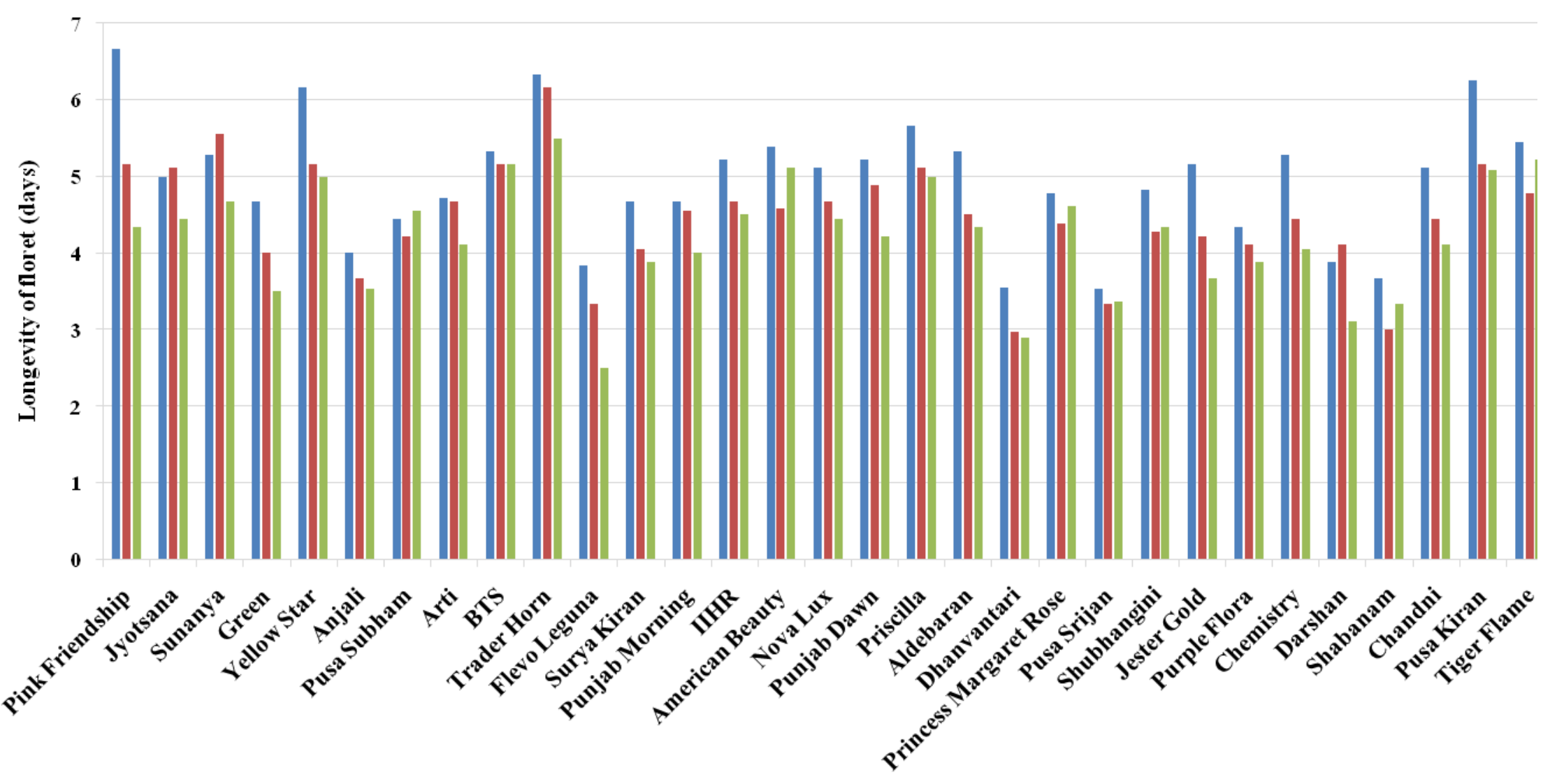

L ongevity of 1st floret $\quad$ Longevity of 3rd floret $\quad$ L ongevity of 5 th floret 
Maximum number of open florets at a time per spike (8.00) was recorded with cv. Nova Lux which was statistically at par with the cv. Pink Friendship (7.33) and significant to other varieties whereas minimum was found with Punjab Morning (4.48).

Maximum number of florets per spike was recorded in cultivar Pink Friendship (18.66) which was at par with cultivars Shubhangini (17.72), and Pusa Kiran (16.41) whereas it was exhibited significant differences with other cultivars. The minimum number of florets per spike recorded in cultivar Aldebaran (6.50). Variation in number of florets per spike was also registered by Negi et al., (2014), Kadam et al., (2014), Rao et al., (2015), Swaroop et al., (2017). The highest longevity of first floret was observed in cv. Pink Friendship whereas minimum longevity of first floret was observed in the cultivar PusaSrijan. The highest longevity of third floret and of fifth floret was observed in Trader Horn and found minimum in the cultivars Dhanvantari and FlevoLeguna for third and fifth floret, respectively (Fig. 2). Variations in days to opening of florets and longevity of florets were also reported by Sindhu et al., (2014), Kadam et al., (2014) and difference in these flowering traits also observed by Singh et al., (2015), Singh and Sisodia (2015) and Singh et al., (2017). Maximum length of first and fifth floret was recorded with cv. American Beauty and with $\mathrm{cv}$.Shabanam for length of third floret, whereas cultivar FlevoLeguna found shorter for length of first, third and fifth floret (Table $2)$. Difference in length of floret and longevity of floret were reported by Nareshet al., (2015), Mushtaq et al., (2018). The longevity of spike was significantly higher in cultivar Shubhangini (17.33 days) and statistically at par with the cultivars Tiger Flame (16.78 days), Pink Friendship (16.67 days), Sunanya (16.00 days) Pusa Kiran (15.91 days). The minimum longevity of spike was recorded for cultivar Aldebaran (9.83 days). Variation in longevity of spike on plant was found by Sarkar and Chakraborty (2014), Sindhu et al., (2014), Chourasia et al., (2015), Singh et al., (2017). Variation in flowering traits was also observed by Singh $e t$ al., (2013) in tuberose.

\section{References}

Choudhary M., Moond, S.K., Kumari, A. and Beniwal, B.S. (2012). Genetic variability in quantitative characters of gladiolus (Gladiolus xhybridus Hort.). International Journal of Agricultural Science,8(1): 138- 141.

Chourasia, A., Viradia, R.R., Ansar, H. and Madle, S.N. (2015). Evaluation of different gladiolus cultivars for growth, flowering, spike yield and corm yield under Saurashtra region of Gujarat. The Bioscan, 10(1): 131-134.

Kadam, G.B., Kumar, G., Saha, T.N., Tiwari, A.K. and Kumar, R. (2014). Varietal evaluation and genetic variability studies on gladiolus. Indian Journal of Horticulture, 71(3): 379-384.

Kumar, P.H. and Kulkarni, B.S. (2009). Genetic variability in gladiolus for growth and flowering characters (Gladiolus hybridus Hort.). Journal of Horticultural Science, 4(2): 177-180.

Momin, B.C., Sunil, K., Momin, K.C. and Niki, D. (2015). Evaluation of gladiolus (Gladiolus grandiflorus L.) genotypes under West Garo Hills district, Meghalaya. HortFlora Research Spectrum, 4(3): 224-229.

Mushtaq, S., Hafiz, I.A., Arif, M. and Anwar, A. (2018). Performance evaluation of elite gladiolus cultivars under agro climatic conditions of Rawalpindi. Asian Journal of Advances in Agricultural Research, 5(3): 1-6.

Negi, R., Kumar, S. and Dhiman, S.R. (2014). Evaluation of different cultivars of 
gladiolus (Gladiolus grandiflorus L.) suitable for low hills of Himachal Pradesh. Indian Journal of Scientific Research and Technology, 2(6): 6-11.

Pandey, R.K., Bhat, D.J.I., Dogra, S., Singh, A., Laishram, N. and Jamwal, S. (2012). Evaluation of gladiolus cultivars under subtropical conditions of Jammu. International Journal of Agriculture Sciences, 8(2): 518-522.

Rao, K.D. and Sushma, K. (2015). Performance of different new genotypes of gladiolus. Agricultural Science Digest-A Research Journal, 35(2): 134-137.

Sankari, A., Anand, M. and Arulmozhiyan, R. (2012). Evaluation of gladiolus cultivars in Eastern Ghats of Tamil Nadu. Journal of Horticultural Sciences, 7(2): 206-208.

Shaukat, S.A., Shah, S.Z.A., Shaukat, S.K. and Shaukat, S.W. (2012). Evaluation of different gladiolus cultivars under Union Council BangoinPoonch J\&K conditions. Journal of Central European Agriculture, 14(2): 138-141.

Singh, A.K. and Sisodia, A. (2017). Textbook of Floriculture and Landscaping, New
India Publishing Agency, New Delhi. pp. 432.

Singh, A. K., Sisodia, A., Sisodia, V. and Ray, P. (2017). Performance of Indian and exotic varieties of gladiolus under Eastern UP conditions. Journal of Ornamental Horticulture, 20(3\&4): 153-157.

Singh, A.K. (2014). Breeding and Biotechnology of Flowers, Vol I: Commercial Flowers. New India Publishing Agency, New Delhi. pp: 705.

Singh, A.K. and Sisodia, A. (2015). Effect of gamma irradiation on morphological changes, flowering and induced mutants in gladiolus. Indian Journal of Horticulture, 72(1): 84-87.

Singh, A.K., Kumar, Amresh and Sisodia, Anjana. (2013). Growth, flowering and bulb yield in tuberose as influenced by cultivars. Environment and Ecology, 31(4A): 1823-1825.

Susila, T. (2013). Evaluation of gladiolus varieties for Visakhapatnam District of Andhra Pradesh. Indian Agricultural Science Digest, 33(3): 237-238.

\section{How to cite this article:}

Anil K. Singh, Dhananjay Kumar, Anjana Sisodia and Minakshi Padhi. 2018. Varietal Evaluation of Gladiolus for Flowering Attributes Under Indo-Gangetic Plains. Int.J.Curr.Microbiol.App.Sci. 7(07): 3728-3735. doi: https://doi.org/10.20546/ijcmas.2018.707.431 